\title{
TUBG2 wt Allele
}

National Cancer Institute

\section{Source}

National Cancer Institute. TUBG2 wt Allele. NCI Thesaurus. Code C52450.

Human TUBG2 wild-type allele is located in the vicinity of $17 q 21$ and is approximately $8 \mathrm{~kb}$ in length. This allele, which encodes tubulin gamma-2 chain protein, plays a role in the organization of microtubules. 